NBER WORKING PAPER SERIES

\title{
ANALYZING THE EXTENT AND INFLUENCE OF OCCUPATIONAL LICENSING ON THE LABOR MARKET
}

\author{
Morris M. Kleiner \\ Alan B. Krueger \\ Working Paper 14979 \\ http://www.nber.org/papers/w14979
NATIONAL BUREAU OF ECONOMIC RESEARCH
1050 Massachusetts Avenue
Cambridge, MA 02138

May 2009

We thank participants at the National Bureau of Economic Research Workshop, Princeton Data Improvement Initiative Conference, and the Industrial Organization and Labor Economics Senimars at Tel Aviv University for their comments. We gratefully acknowledge help from Edward Freeland and the staff at Princeton's Survey Research Center, the Industrial Relations Section at Princeton University, and the staff at Westat. We also thank Joan Gieseke, Matthew Hendricks and Samuel Kleiner for assistance. The views expressed herein are those of the author(s) and do not necessarily reflect the views of the National Bureau of Economic Research.

NBER working papers are circulated for discussion and comment purposes. They have not been peerreviewed or been subject to the review by the NBER Board of Directors that accompanies official NBER publications.

(C) 2009 by Morris M. Kleiner and Alan B. Krueger. All rights reserved. Short sections of text, not to exceed two paragraphs, may be quoted without explicit permission provided that full credit, including (c) notice, is given to the source. 
Analyzing the Extent and Influence of Occupational Licensing on the Labor Market

Morris M. Kleiner and Alan B. Krueger

NBER Working Paper No. 14979

May 2009

JEL No. J08,J44,J58,J80,K23,K31,L38,L5,L51

\begin{abstract}
This study examines the extent and influence of occupational licensing in the U.S. using a specially designed national labor force survey. Specifically, we provide new ways of measuring occupational licensing and consider what types of regulatory requirements and what level of government oversight contribute to wage gains and variability. Estimates from the survey indicated that 35 percent of employees were either licensed or certified by the government, and that 29 percent were fully licensed. Another 3 percent stated that all who worked in their job would eventually be required to be certified or licensed, bringing the total that are or eventually must be licensed or certified by government to 38 percent. We find that licensing is associated with about 14 percent higher wages, but the effect of governmental certification on pay is much smaller. Licensing by multiple political jurisdictions is associated with the highest wage gains relative to only local licensing. Specific requirements by the government for a worker to enter an occupation, such as education level and long internships, are positively associated with wages. We find little association between licensing and the variance of wages, in contrast to unions. Overall, our results show that occupational licensing is an important labor market phenomenon that can be measured in labor force surveys.
\end{abstract}

Morris M. Kleiner

University of Minnesota

Humphrey Institute

260 Humphrey Center

30119 th Street South

Minneapolis, MN 55455

and NBER

kleiner@umn.edu

Alan B. Krueger

Industrial Relations Section

Firestone Library

Princeton University

Princeton, NJ 08544

akrueger@princeton.edu 


\section{Introduction}

Occupational licensing as a topic in economics dates back at least to the comments by Adam Smith that trades conspire to reduce the availability of skilled craftsmen in order to raise wages (Smith, 1937). The public policy and legal communities, however, have noted that regulating occupations in order to protect the public against incompetent, untrustworthy, or irresponsible practitioners is in the public interest (Thomas v. Collins, 1945).

Since Friedman and Kuznets’s (1945) classic work, there has been little analysis of the labor market influence of occupational regulation in economics (exceptions are Rottenberg, 1980; Kleiner, 2006; and Kleiner and Krueger, 2008). ${ }^{1}$ A major reason for the lack of empirical work has been the absence of national data that clearly defined whether a worker was regulated and the extent of regulation. The purpose of this study is to probe in greater detail the prospects for measuring occupational licensing in a new detailed labor force survey and to estimate the labor market effects of occupational licensing. Specifically, we delve into what types of regulatory requirements -- and the particular level of government oversight -- may contribute to wage gains and wage variability.

We use the results of a new telephone survey of the workforce conducted by Westat that asked detailed questions on occupational regulation as well as questions on the labor market status of individuals. The survey questions were developed as part of the Princeton Data Improvement Initiative (PDII). These questions probe the kind of government regulation

\footnotetext{
${ }^{1}$ Since 2000 no articles on occupational licensing have appeared in some of the major economic journals, including the American Economic Review, the Journal of Political Economy, the Quarterly Journal of Economics, and Econometrica. During the same period, only one article on licensing has appeared in the Journal of Labor Economics and the Industrial and Labor Relations Review — often regarded as the top two labor economics journals. In contrast, 16 articles on unionization have been published since 2000 in these two journals. Moreover, associations such as the Labor and Employment Relations Association and the International Industrial Relations Research Association have been devoted to research on labor-management issues, but no such academic organizations exist that focus on occupational licensing.
} 
required to perform a job, the process of becoming licensed, and the level of education and tests necessary to become licensed. Results of the Westat survey, as well as separate validation results from a Gallup survey, indicate that occupational licensing can be reasonably well measured in labor force surveys.

Turning to the substantive results, we find that licensing is associated with about 14 percent higher wages, but government certification has a much smaller association with pay. Licensing by multiple political jurisdictions, such as regulation by the states and the federal government, is associated with higher wage gains than local regulations. Specific requirements by the government to enter an occupation, such as education level and long internships, are positively associated with wages. This pattern of results is consistent with a monopoly model of occupational licensing; where supply is more restricted if the licensing authority operates on a wider geographic level.

\section{Background on Characteristics of Licensing}

Occupational regulation in the United States generally takes three forms. The least restrictive form is registration, in which individuals file their names, addresses, and qualifications with a government agency before practicing their occupation. The registration process may include posting a bond or filing a fee. In contrast, certification permits any person to perform the relevant tasks, but the government—or sometimes a private, nonprofit agency_ administers an examination and certifies those who have achieved the level of skill and knowledge for certification. For example, travel agents and car mechanics are generally certified but not licensed. The toughest form of regulation is licensure; this form of regulation is often referred to as "the right to practice.” Under licensure laws, working in an occupation for compensation without first meeting government standards is illegal. In 2003 the Council of State 
Governments estimated that more than 800 occupations were licensed in at least one state, and more than 1,100 occupations were licensed, certified, or registered (Council on Licensure, Enforcement and Regulation [CLEAR], 2004).

Prior to our survey, the data available on occupational licensing in the U.S. was restricted to classifications as to whether various occupations were licensed at the state level, often based on the CLEAR data. These classifications could be linked to Census occupational employment data to derive estimates of the proportion of workers in licensed jobs. While informative, there are clear limitations of such data. First, compliance with state licensing requirements could be less than complete; some of these classified as working in licensed occupations may not in fact be licensed. Second, in some occupations there is a trial period when workers can work in a job before becoming licensed. Third, and probably most important, the state data miss licensing that takes place at the local and federal level.

Despite these serious limitations, the state-level data show some striking trends. During the early 1950s, less than 5 percent of the U.S. workforce was in occupations covered by licensing laws at the state level (Council of State Governments, 1952). That number grew to almost 18 percent by the 1980s—-with an even larger number if federal, city, and county occupational licensing is included. By 2000, the percentage of the workforce in occupations licensed by states was at least 20 percent, according to data gathered from the Department of Labor and the 2000 Census. In contrast, during this period no systematic attempts were made to gather information on licensing or its wage or employment effects at the federal or local level.

As employment in the United States shifted from manufacturing to service industries, which typically have lower union representation, the members of the occupations established a 
formal set of standards that governed members of the occupation. For a professional association, obtaining licensing legislation meant raising funds from members to lobby the state legislature, particularly the chairs of appropriate committees. In addition, the occupation association often solicits volunteers from its membership to work on legislative campaigns. With both financial contributions and volunteers, the occupational association has a significant ability to influence legislation and its administration, especially when opposition to regulatory legislation is absent or minimal (Wheelan, 1998). The large potential gain from regulation through increased demand for the service, enhanced earnings, and the ability to restrict supply outweighs the potential losses to consumers of potentially higher prices for the regulated services.

Figure 1 shows trends in the growth of occupational licensing and unionization from 1950 to $2008 .^{2}$ Licensing data for earlier periods are available only at the state/occupational level; the data gathered through the Gallup and Westat surveys for 2006 and 2008 are denoted with a dashed line in the figure. Despite possible problems in both data series, occupational licensing clearly is rising and unionization is declining. By 2008, approximately 29 percent of workers polled in the Westat survey said they were required to have a government-issued license to do their job, compared with about 12.4 percent who said they were union members in the Current Population Survey (CPS) for the same year.

\section{Wage Determination and Licensing: Background}

\footnotetext{
${ }^{2}$ The method used to calculate the percentage licensed prior to 2006 first involved gathering the listing of licensed occupations in each state by Labor Market Information units under a grant from the U.S. Department of Labor (see America's Career InfoNet, http://www.acinet.org/acinet/licensedoccupations/lois occ.aspx?stfips=27\&by=occ\&keyword=\&searchType=\&). This was matched with occupations in the 2000 Census. If no match was obtained, the occupation was dropped. From the Census the number working in the licensed occupation in each state was estimated and used to calculate a weighted average of the percentage of the workforce in the United States that works in a licensed occupation. For 2008 we deleted individuals who were certified from our tally of individuals who were either licensed or certified in our survey conducted by Westat.
} 
How can licensing raise wages? Unlike unions, which can engage in concerted activities such as strikes or work slowdowns, licensed workers do not sign collective agreements with their employers. Nor do they engage in strikes against employers to raise wages. Occupational licensing can affect pay and employment through three main channels. First, licensing may increase quality by imposing initial education, testing, continuing training requirements, internship requirements, or fees. These requirements are likely to diminish the number of less qualified or unmotivated individuals who could enter the occupation, and thereby serve to drive up the average quality of workers in an occupation. A consequence is higher quality outcomes for those who are able to obtain the service, but fewer practitioners and less access to the service.

Second, by using the state to monitor and prevent the potential work effort of unlicensed workers, competition by unlicensed individuals is virtually eliminated through the use of the state’s enforcement powers. For example, the work of "hair braiders," which is unlicensed, could be brought under the control of the cosmetology board and limited to only licensed cosmetologists or barbers (Anderson v. Minnesota Board of Barber and Cosmetology Examiners, 2005). Further, when demand fluctuates for traditional tasks, the board has the ability to expand the regulated work through establishing administrative rules and limiting the work of unregulated workers. Third, the regulatory board through its administrative procedures of establishing large entry barriers and moral suasion can reduce the number of openings in schools that prepare individuals for licensed positions. In addition, by adjusting the pass rate on the licensing exam, they can change the number of new entrants from instate or migrants from other states or nations (Tenn, 2001, Pagliero, 2009). 
Some evidence suggests that licensing does restrict the supply of workers in regulated occupations. One application focuses on the comparison of occupations that are licensed in some states and not in others. The occupations examined were librarians (licensed in 19 states), respiratory therapists (licensed in 35 states), and dietitians and nutritionists (licensed in 36 states) from 1990 to 2000 using Census data (Kleiner, 2006). Using controls for state characteristics, the multivariate estimates showed that in the states where the occupations were unlicensed there was a 20 percent faster growth rate than in states that did license these occupations. Another study found that the imposition of greater licensing requirements for funeral directors is associated with fewer women holding jobs as funeral directors relative to men by 18 to 24 percent (Cathles, Harrington, and Krynski, 2009).

Studies of the effects of licensing on wages have, in many ways, paralleled the research methods used to study the effect of unions on wages (Lewis, 1986). These approaches include cross-section estimates, switchers from regulated to unregulated and vice versa over time, and cross-sectional results from within occupation comparisons. The general estimates of crosssectional studies using Census data of state licensing's influence on wages with standard labor market controls show a range from 10 to 15 percent for higher wages associated with occupational licensing. Estimates were developed from the National Longitudinal Survey of Youth (NLSY) from 1984 to 2000 and show the difference in wages between changers from unlicensed to licensed occupations and between those who move from a licensed occupation to an unregulated one. The estimates show an impact of about 17 percent of moving to a licensed occupation relative to moving from a licensed occupation to an unlicensed one. However, within-occupation wage variations both for service occupations and for individuals in jobs that repair things suggest a wide range of wages changes from zero to 40 percent of regulation within 
an occupation. Although these results suggest that licensing —-the toughest form of regulationmatters for wage determination, these estimates do not use national estimates, do not examine the levels of government that matter, and do not consider the influence of the requirements to become licensed, such as education, testing, or internships that may further enhance wages.

\section{The Survey Instrument and Design}

Our survey is part of the PDII, a multi-researcher project to develop new questions and methods for economic surveys. The questionnaire was patterned after the CPS and included additional questions on career experience, job tasks, and offshorability of jobs. In the summer of 2008, Westat (www.westat.com) conducted a national random digit dial (RDD) survey on behalf of Princeton University. Princeton provided Westat with a draft of a questionnaire at the start of the project. Princeton and Westat collaborated in finalizing the question order and wording. A number of the questions had been developed and tested in earlier work by Princeton and under prior task order contracts with Westat. Several questions regarding the respondent’s employer, job activities, and demographics were taken from the CPS. Westat programmed the questionnaire and skip patterns for administration by Computer Assisted Telephone Interviewing (CATI), in both English and Spanish. Westat staff pretested the instrument with several volunteer respondents. This pretest suggested several additional revisions for the questionnaire, including shortening it to achieve the targeted average interview length of 15 minutes.

Westat conducted the survey from June 5 to July 20, 2008. ${ }^{3}$ Individuals age 18 or older who were in the labor force were eligible for the survey. A total of 2,513 individuals were interviewed. We limit our analysis to those who were employed at the time of the survey. Westat

\footnotetext{
${ }^{3}$ The questionnaire and codebook are available at http://www.krueger.princeton.edu/PDIIMAIN2.htm.
} 
used a RDD sampling design constructed from a national sampling frame of residential exchanges. The selected numbers were called and screened to identify households with eligible respondents. One respondent was randomly selected from each eligible household to complete the survey using the nearest birthday procedure. Up to 15 callbacks were made to try to elicit responses. Some 28 percent of sampled eligible households agreed to participate in the screening of questions, and 64 percent of the selected individuals in screened households completed the questionnaire. Thus, the response rate was 17.9 percent, using the American Association for Public Opinion Research response rate definition 3 (see aapor.org/uploads/Standard_Definitions_04_08_Final.pdf, p. 35). ${ }^{4}$

Although the survey response rate is low compared to many government labor force surveys, it is comparable to that in commercial surveys. While the low response rate is potentially worrisome, Groves and Peytcheva (2008) show that survey nonresponse rates by themselves are not necessarily associated with significant bias. Low response rates are a concern when the causes of participation in the survey are correlated with the survey variables of interest. We suspect that occupational licensing is not strongly associated with the tendency to complete the survey. The response rate was low in large part because many households declined to participate in the screener questions, which did not mention occupational licensing. Another reason for placing some confidence in the representativeness of our sample is that a standard

\footnotetext{
${ }^{4}$ Among the households, 18,520 telephone numbers were screened to be residential. Of these, 4,079 households had eligible persons and 2,086 did not, meaning that the latter households had no adults in the labor force at the time of the interview. For the remaining residential telephone numbers $(12,355)$, it was not possible to ascertain eligibility status. Therefore, an eligibility status adjustment was performed using new adjustment cells defined by the Census Region, Metropolitan Statistical Area status, and median income of the telephone exchange. Five median income categories were defined, and there were altogether 50 adjustment cells.
} 
Mincerian wage regression using data from the survey closely matched the corresponding regression from the CPS (see the Appendix). Although we would have preferred a higher response rate, we have no reason to believe that nonresponse skews our results in favor of finding more or less occupational licensing and certification, or particular associations between licensing and certification and earnings.

Westat developed survey weights to compensate for variation in selection probabilities, differential response rates, and possible under coverage of the sampling frame. The derivation of the sample weights focused primarily on matching the marginal distributions of the CPS by sex, age, educational attainment, census region, urbanization, race, Hispanic ethnicity, employment status, and class of employer (private, government, etc.).

Westat collected information on the location where the license or certificate was registered for a random sample of 221 respondents who answered yes to a question that they were licensed. Westat subsequently used this information to try to verify whether the respondent had a valid occupational license or certificate. Our results show that of the 71 individuals for whom Westat could find information, 20 were believed to have answered the question incorrectly and 5 were found to have an inactive license or other status. For the individuals that Westat could verify, 47 could be found through a government database that was publicly available. Consequently, two-thirds of the sample could be easily verified as having a government license. $^{5}$

\footnotetext{
${ }^{5}$ Of the 20 respondents that were believed to answer incorrectly, 11 indicated they were licensed at the federal level, 15 at the state level, and 11 at the local level. About half of the respondents indicated that they were required to have a license by more than one level of government, and that the inability to find the license could be an issue of the surveyor looking at the incorrect level of government, or that the data were not listed on a readily accessible computer within the department.
} 


\section{Questionnaire and Data}

We designed a module to assess the accuracy of self-reported occupational licensing and certification. The key questions were as follows:

Q11. Do you have a license or certification that is required by a federal, state or local government agency to do your job?

YES 1

NO 2 (Go to Q25)

IN PROCESS/WORKING ON IT. 3

Q11a. Would someone who does not have a license or certificate be legally allowed to do your job? YES 1

NO 2

Q12. Is everyone who does your job eventually required to have a license or certification by a federal, state or local government agency?

YES 1

NO 2

Those who answered affirmatively to Q11 were asked additional questions about the agency (federal, state or local) that required their license or certificate, and the requirements they needed to satisfy, such as achieving a high school or college degree, passing a test, demonstrating certain skills, or completing an internship or apprenticeship.

The responses to our analysis showed that 35 percent of the respondents answered that they were either licensed or certified in question 11. Approximately 6 percent stated that individuals who did not have a license could do the work in question 11a, which is the definition of government certification. Another 3 percent stated that all who worked would eventually be required to be certified or licensed, bringing the total that are or eventually must be licensed or certified by government to 38 percent. 
To further examine the test-retest validity of our results for the licensing question, we examined the consistency of responses over several days of the week using data gathered from a time use survey by the Gallup Organization. The Gallup survey asked individuals on Thursday and Saturday whether they were licensed. In Table 1 we show the consistency of the responses in comparison to a question on years of education. Of the responses, 98.2 percent were consistent in their responses for licensing, but only 91.1 percent provided consistent answers when stating their level of education on two different days that were three days apart. Overall, individuals are internally consistent and apparently reliable in reporting whether they hold a license from government in order to do their work.

\section{Who Is Licensed?}

To explore the basic demographic and economic characteristics of regulated workers, we examine the distribution of licensed occupations by education, race, union status, public or private sector, and gender in Table 2. The results indicate that licensing rises with education: more than 40 percent of those with post college education are required to have a license compared to only 15 percent for those with less than a high school education. The results in the Table show that union members are more likely to be licensed, reflecting in part the large number of teachers and nurses who tend to be both union members and licensed. Government workers are more likely to have a license than nongovernment workers, but there is no difference in the rate of licensing by gender.

We find similar licensing rates for men and women, whites, blacks, and Hispanics. The table also shows that licensing rises with age and then declines slightly over age 54 . Table 2 also presents further the distribution by industry and union status. Licensing is also much more 
prevalent for those who provide services or repair items than those who make things on their jobs.

The questionnaire also asked questions about the governmental level of licensing for the individuals in our sample. In our survey about two-thirds of the licensed individuals in our sample are licensed at the state level, followed by the federal and local levels. In general occupations commonly required to have state licenses range from attorneys and dentists to dental hygienists and mortgage brokers. Individuals who usually are federally licensed workers range from workers such as quality assurance inspectors for the Federal Aviation Administration to stockbrokers. At the local level, taxi drivers and massage therapists are often licensed by this political jurisdiction. The federal courts have largely left licensing as a state issue, since this is the level of government that has largely regulated workers in the United States (Dent $v$. West Virginia, 1888). Nevertheless, the courts have determined that licensing by the states can contradict the Sherman Act (Goldfarb v. Virginia, 1975). The Supreme Court ruled that the state attorney bar association's policy of a minimum fee schedule violated the Sherman Act's prohibition of combinations in restraint of trade. The Court ruled that the legal profession was not a public service, but rather a market-driven service. These court decisions have made the focus of most licensing as largely a state legal and economic policy issue rather than a federal or local issue.

The requirements necessary to enter an occupation potentially influence the quality of services rendered and serve as a barrier to entry. Table 3 gives the percentage of licensed workers from our survey data that require a college education, a high school education or GED, an internship or apprenticeship, passage of a test, demonstration of qualifications, fees, 
continuing education, and continued testing to maintain a license. For example, 85 percent of those persons licensed were required to take an exam, almost 70 percent were required to take continuing education classes, more than half require an internship, and almost 43 percent require at least a college education. Each of the requirements can enhance the quality of the practitioners in the occupation or restrict entry and thereby reduce competition for performing the work.

\section{Occupational Regulation and Wages}

To examine whether licensing is associated with higher pay, we present estimates of log wage regressions in the estimated model in Table $4 .{ }^{6}$ We augment a standard earnings equation to include a dummy variable indicating whether a license is required for the worker's job. We regard these estimates as mainly descriptive, since licensed workers may differ from unlicensed workers in unobserved ways, even after we condition on education and occupation. If a dummy indicating license status is added to a standard wage equation, having a license is associated with approximately 14 percent higher hourly earnings depending on the detail of the specification of occupational control variables ( $p$-value $<0.001)$. When we include detailed occupation controls such as two-digit ones in column 2, the coefficient rises to .199 and then falls when four-digit controls are introduced in column 3, but the coefficient on licensing is still a robust 11 percent. $^{7}$ The cross-sectional effect of licensing is similar in magnitude to the estimated effect of belonging to a union (see Lewis, 1986), and greater than an additional year of schooling. The

\footnotetext{
${ }^{6}$ We also attempted to instrument for licensing by using the state licensing for occupation such as electricians, plumbers, and teachers but were not able to find a robust instrument in our first stage estimates. Additional attempts at finding appropriate instrumental variables (IVs ) included political affiliation of the state, state of residence, and union coverage in the state, but with limited predictive power.

${ }^{7}$ Our estimates show no differences in the influence of licensing by gender. Further, by not including a licensing variable, the impact of unionization is biased upward in a standard wage equation.
} 
regression estimates also include educational attainment, age, self employment, career experience and its square, union status, and industry and occupation dummy variables. ${ }^{8}$

A distinguishing characteristic of the Westat survey is that the variable for career experience is the reported actual experience of the respondents rather than an estimate based on age and education (Blau and Kahn, 2008). Specifically, the question for experience was: "Since age 18, in how many years altogether have you worked for pay or profit? Please count all years in which you worked either all or part of the year.” The variable tracked well the traditional variable for experience used in human capital analysis. A major policy issue for the governmental regulation of occupations is the role for certification, which allows others to do the work but allows individuals to earn a title that signifies that they achieved certain requirements. Unlike licensing, for certification there are no restrictions other than titling for doing the task for pay. ${ }^{9}$ In Table 5 we estimate wage equations similar to those in Table 4 using largely the same covariates but add an indicator for certification status. We find that the certification variables, although positive, are usually not statistically significant and the coefficients are of a much smaller in magnitude than was found for licensing, averaging between 7 and 11 percent. When more occupational details are added, the coefficients rise to 11 percent with two-digit controls but fall to 7 percent when four-digit controls are added with less precisely estimated coefficients.

\footnotetext{
${ }^{8}$ We also estimated all the wage equations for only occupations that were regulated in some states and not in others, (e.g., interior designers and mortgage brokers). Our estimates show that that licensing was always statistically significant, with point estimates ranging from 9 to 17 percent. There was no qualitative change in the estimates by dropping universally licensed occupations from the analysis of the survey. These estimates are available from the authors.

${ }^{9}$ The nomenclature surrounding licensing and certification can be confusing. For example, a Certified Public Accountant (CPA) is licensed rather than certified as we use the terms as someone who is not qualified as a CPA cannot perform the work of a CPA.
} 
The results of these wage equations are consistent with the interpretation that licensing policy enables the individuals in a licensed job to obtain a degree of monopoly control, or the ability to "fence out" competitors for a service, which results in increased wages for licensed workers. Licensing policies, with regulations that require additional effort to get into the occupation, matter more in wage determination than the government merely giving its approval of a title for an occupation.

To further probe the role of occupational licensing, we next examine whether the level of governmental jurisdiction that issues occupational licenses matters for wage determination. Specifically, as shown in Table 6, we allow for a differential effect of licensing at the county or city, state, or federal level. In our sample, 49 percent of the respondents reported that they were licensed at only one level of government, while the others reported that they had licenses from more than one governmental venue. A basis of comparison in our estimates is individuals who have a license but do not need it for their jobs. For example, a manager in a large firm may be a licensed attorney, but his or her license is not required for the position. Our estimates are intended to examine the influence of having one or multiple jurisdictional levels of licensure on wages. Overall, licensing at the state level is associated with the largest and most consistent effect on wages. As shown in the first row of Table 6, licensing at the state level is associated with earnings growth of 9 to 17 percent, depending on the number of occupational control variables. None of the other political jurisdictions show precisely estimated coefficients across the three specifications with varying numbers of occupational controls. Further, the interaction of state with either federal or local government levels of regulation is precisely estimated with coefficient estimates ranging from 20 to 26 percent. 
Our results show the largest influence of the level of government licensing on wages is greatest at the state and federal levels. Local licenses are not associated with pay increases. Potential reasons for the decline in the precision of the estimates for licensing at the local level may be that licensing for low-paid jobs, such as taxi licenses and tattoo parlors, are often left to local governments. Further, local licensing is less likely to be a restriction on competition than state or federal licensing, since customers can call a taxi from an unlicensed jurisdiction or visit a neighboring town for a tattoo. Based on these estimates, we conclude that licensing is a labor market institution that matters in wage determination at least as much unionization.

\section{Probing the Anatomy of Wage Effects}

What elements of licensing requirements contribute to the wage advantage captured by licensed practitioners? In Table 7 we probe the provisions of licensing regulations that enhance the wage premium of regulated practitioners. In order to obtain a license, individuals in occupations often are required to meet general education requirements that include graduation from high school or college, and occupation-specific requirements such as a long internship, some lasting more than a year, and attending continuing education classes following entry into the field. In addition, for entry into an occupation, passing an examination is generally required. The effects of testing for entry is an issue that has been raised by Milton Friedman and others, who hypothesized and provided evidence that the members of the occupation can manipulate the pass rate to restrict entry and raise wages (Friedman, 1962; Maurizi, 1974; Kleiner and Kudrle, 2000; and Kleiner, 2006). Although we find that the provision of requiring a college education is associated with an hourly pay increase of more than 17 percent (Table 7, column 1) with no occupational controls, the result is not robust to specifications that add additional occupational 
controls. None of the other specific requirements are robust in their statistical significance across all specifications; however, the requirements together are all significant at the $p$-value $<0.01$ using an F-test for the joint significance of the requirements to obtain and maintain a license in the specifications in the table. The requirements for entering and remaining in a licensed occupation may act in a nonlinear manner to enhance the earnings of practitioners.

\section{Job Tasks of Regulated Practitioners}

Do licensed occupations perform more sophisticated cognitive work tasks, such as doing difficult math and reading assignments? If so, perhaps the wage premium is economic returns to higher cognitive abilities and tasks. Moreover, are licensed or government-certified tasks more education-intensive, which would account for some of the wage premium obtained by regulated workers? In order to address this question using the data from the PDII survey, we examine question 25, which asks the self-reported use of math and reading abilities of the practitioners. For example, the reading question asks: "What (is/was) the longest document that you typically read as part of your job?” And the math question asks: “How often (do/did) you solve problems at your jobs using advanced mathematics such as algebra, geometry, trigonometry, probability, or calculus?”

Table 8 analyzes reading utilization, and Table 9 examines math use when occupational regulation is taken into account. The estimates in these tables show that regulated practitioners are somewhat more likely to do more reading tasks at their workplace, controlling for standard

human capital, demographic, and occupation variables that are available in the survey. Although licensed workers have a positive, albeit small, impact on reading use, certified workers, such as librarians and technicians, are much more likely to engage in detailed reading relative to either 
unregulated or licensed practitioners. Table 9 shows that regulated occupations do more mathrelated tasks (see column 1), but the influence is diminished once controls for detailed occupations are added. Although licensed occupations appear to do somewhat more work that requires cognitive tasks, the results of the influence of occupational regulation vary when the detailed occupations are included.

\section{Does Licensing Influence Wage Dispersion?}

In order to examine the influence of licensing on the variance in wages, we examine the mean within category squared residual from a log of wage regressions in both licensed and unlicensed occupations, controlling for human capital characteristics. We also compare union and nonunion earnings as a point of reference, since unions have been shown to reduce variations in wages (Freeman, 1982). Table 10 presents the mean residual variance in each sector and the difference between licensed and unlicensed jobs. The measure of dispersion of wages among licensed jobs is about the same as or only slightly smaller than that among unregulated ones and the $p$-value for difference in the mean squared error is not significant. In contrast, the lower part of the table shows that unionization reduces the variance in wages. These results are similar to those found with a different data set in Kleiner and Krueger (2008), suggesting the robustness of the findings for the role of unions and licensing over time and across different surveys.

\section{Conclusions}

We show that occupational licensing is an important labor market phenomenon that is pervasive and likely has a large influence on wage determination. Using a specially designed survey of a nationally representative sample of Americans carried out by Westat, we provide an 
examination of the prevalence and influence of various forms of occupational licensing. We show that the consistency of reporting in having a license is high, but that it is more difficult to externally verify licensing through government databases, in part due to the lack of on-line or computer-readable data of licensed practitioners by states and local governments.

Licensing is a growing phenomenon in the U.S. economy, reaching almost 29 percent of workers in our 2008 survey. Workers who have higher levels of education are more likely to work in jobs that require a license, and most licensing is implemented at the state level. The requirement of government regulation, especially regulation at both the state and local level or the state and federal level, is associated with higher wages relative to those in jobs that only require local licensing. Certification, a weaker form of government regulation that allows others (noncertified workers) to work in the occupation, has a much smaller effect on wages. Workers who are licensed or certified do work that is associated with greater use of reading and somewhat more use of mathematical tasks. Unlike unions, which appear to reduce wage variation, licensing does not appear to diminish wage variation.

On balance, our results also lend support for the interpretation that occupational licensing serves as a means to enforce entry barriers to a profession that raise wages. Furthermore, our finding that licensing is associated with a larger wage premium when the license is issued at the state as opposed to local level suggests that competition is more effectively restricted when there is no possibility of obtaining a service from an unlicensed provider in a nearby locality. Our estimates of the relationship of occupational licensing and wages is consistent with the hypothesized role by members of an occupation to raise wages by using the powers of government to drive up requirements and capture work for the regulated workers for larger 
geographic areas. These estimates suggest a strong role for the monopoly face of licensing in the labor market. Indeed, the wage premium associated with licensing is strikingly similar to that found in studies of the effect of unions on wages (Freeman and Medoff, 1984, Lewis, 1986). It is possible, however, that omitted variables are correlated with both licensing and wages, which confound our results. With the large and growing number of workers required to obtain an occupational license, and the apparently large effect of licensing requirements on the labor market, we think it would be prudent for statistical agencies to measure and monitor the extent of occupational licensing. This can be accomplished in a manner similar to the way in which information is collected for unions in labor force surveys, such as the CPS. We have demonstrated how such questions can be asked in a labor force survey, and have provided some indication of the reliability and utility of the resulting data. Adding these questions to a survey like the CPS would help to answer questions such as: How much regulation is optimal for productivity growth? Does occupational licensing lead to better consumer protection and higher quality? How does the licensing premium vary across occupations, industries and regions? Is the pace of occupational licensing rising or falling? And what is the interaction between licensing and unionization? 


\section{References}

Anderson v. Minnesota Board of Barber and Cosmetology Examiners. 2005. Case 05-5467 June.

Blau, Francine, and Lawrence Kahn. 2008. "The Feasibility and Importance of Adding Measures of Actual Experience to Cross-Sectional Data Collection.” Paper presented at the Cornell-Princeton Conference on the Princeton Data Improvement Initiative, October.

Cathles, Alison, David E. Harrington, and Kathy Krynski. 2009. “The Gender Gap in Funeral Directors: Burying Women with Ready-to-Embalm Laws.” Paper presented at the International Symposium on the Government Regulation of Occupations, London School of Economics, March.

Council on Licensure, Enforcement, and Regulation (CLEAR), 2004. http://www.clearhq.org/mission.

Council of State Governments. 1952. Occupational Licensing Legislation in the States. Chicago: Council of State Governments.

Dent v. West Virginia. 1888.129 U.S. 114.

Freeman, Richard B. 1982.“Union Wage Practices and Wage Dispersion within Establishments.” Industrial and Labor Relations Review 36(1): 3-21.

Freeman Richard B. and James Medoff, 1984. What Do Unions Do? New York, Basic Books.

Friedman, Milton. 1962. Capitalism and Freedom. Chicago: University of Chicago Press.

Friedman, Milton, and Simon Kuznets. 1945. Income from Independent Professional Practice. New York: National Bureau of Economic Research. 
Goldfarb v. Virginia. 1975, 421 U.S. 773.

Groves, Robert, and Emilia Peytcheva. 2008. “The Impact of Nonresponse Rates on Nonresponse Bias: A Meta-Analysis.” Public Opinion Quarterly 72(2): 167-189.

Kleiner, Morris. 2006. Licensing Occupations: Enhancing Quality or Restricting Competition?Kalamazoo, MI: Upjohn Institute.

Kleiner, Morris M., and Alan B. Krueger, 2008. “The Prevalence and Effects of Occupational Licensing.” Working Paper 14308, National Bureau of Economic Research, Cambridge, MA, September.

Kleiner, Morris M., and Robert T. Kudrle. 2000. “Does Regulation Affect Economic Outcomes? The Case of Dentistry.” Journal of Law and Economics 43(2): 547-582.

Lewis, H. G. 1986. Union Relative Wage Effects: A Survey. Chicago: University of Chicago Press.

Maurizi, Alex R., 1974. “Occupational Licensing and the Public Interest.” Journal of Political Economy 82, pp. 399-413.

Pagliero, Mario, 2009 “Licensing Exam Difficulty and Entry Salaries in the US Market for Lawyers” Paper presented at the International Symposium on the Government Regulation of Occupations, London School of Economics, March.

Rottenberg, Simon. 1980. “Introduction,” in Occupational Licensure and Regulation. S. Rottenberg, ed. Washington, American Enterprise Institute, pp. 1-10.

Smith, Adam. 1937. The Wealth of Nations.New York: Modern Library.. (Originally published 1776.) 
Tenn, Steven. 2001. "Three Essays on the Relationship between Migration and Occupational Licensing.” Unpublished dissertation, Department of Economics, University of Chicago.

Thomas v. Collins, 323 U.S. 516, 545 (1945).

Wheelan Charles J. 1998. "Politics or Public Interest? An Empirical Examination of Occupational Licensure.” Unpublished manuscript, University of Chicago. 
Figure 1: Comparisons in the Time-Trends of Two Labor Market Institutions: Licensing and

\section{Unionization*}

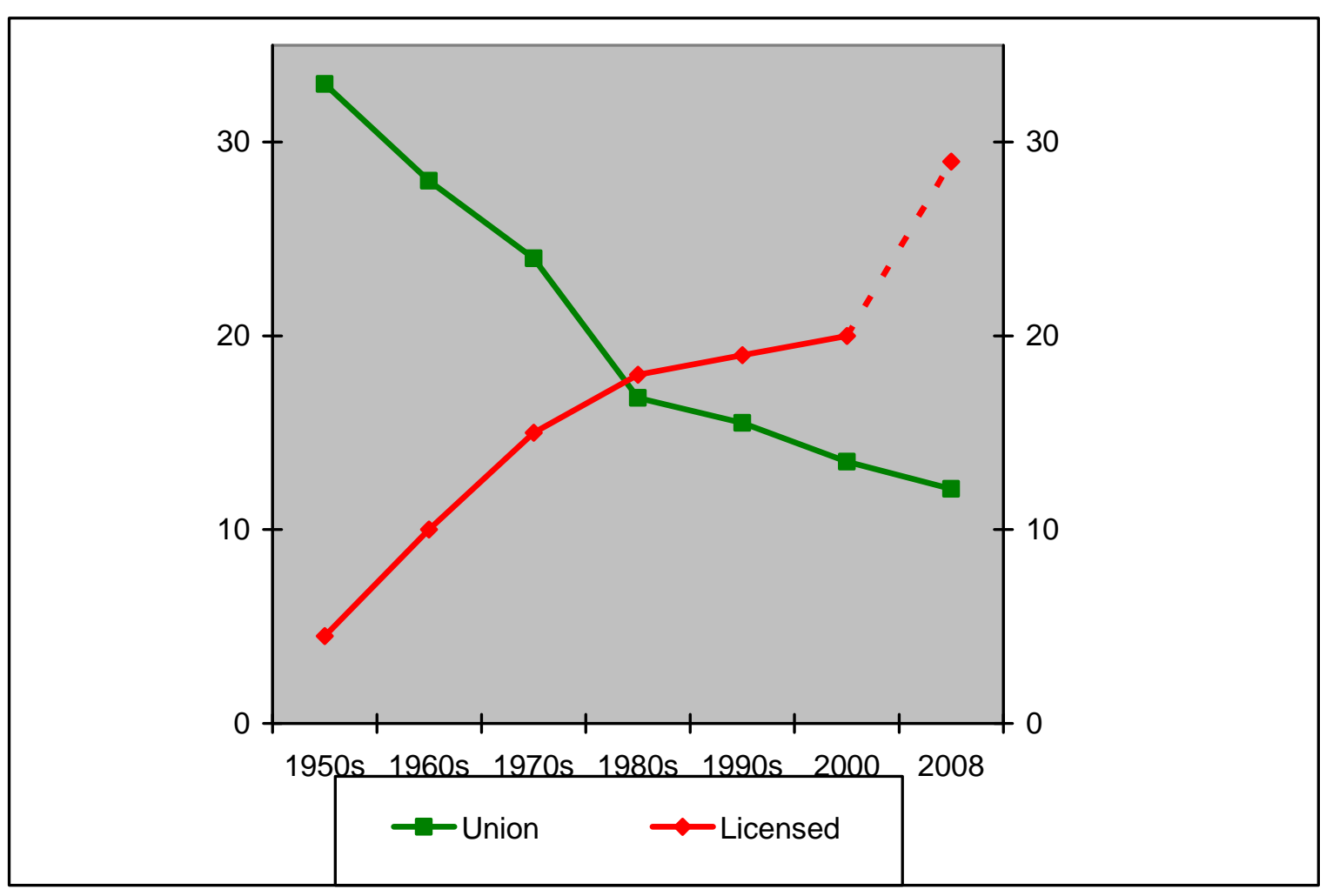

*Dashed line shows the value from state estimates of licensing to the Gallup Survey and Westat Survey results, and the union membership estimates are from the CPS 
Table 1: Gallup Poll Results of Reliability of Licensing and the Level of Education Responses

\begin{tabular}{|c|c|c|c|}
\hline $\begin{array}{c}\text { Licensed } \\
\text { first day agrees with } \\
\text { last day }\end{array}$ & Frequency & Percent & Cumulative \\
\hline Yes & 166 & 98.22 & 98.2 \\
\hline No & 3 & 1.78 & 100.00 \\
\hline Total & 169 & 100.00 & \\
\hline
\end{tabular}

\begin{tabular}{c:c:c:c}
$\begin{array}{c}\text { Education level } \\
\text { first day agrees with } \\
\text { last day }\end{array}$ & Frequency & Percent & Cumulative \\
\hline Yes & 154 & 91.12 & 91.1 \\
\hline No & 15 & 8.88 & 100.0 \\
\hline Total & 169 & 100.00 &
\end{tabular}


Table 2: Characteristics of Licensed and Certified Workers

\begin{tabular}{|c|c|c|}
\hline & \multicolumn{2}{|c|}{ Percentage of Workers: } \\
\hline & Licensed & Certified \\
\hline \multicolumn{3}{|l|}{ Gender } \\
\hline Male & 28.4 & 6.7 \\
\hline Female & 28.7 & 5.0 \\
\hline All & 28.6 & 5.8 \\
\hline \multicolumn{3}{|l|}{ Education Level } \\
\hline Less than HS & 14.5 & 4.0 \\
\hline High School & 19.9 & 5.8 \\
\hline Some College & 28.1 & 5.9 \\
\hline College (BA) & 29.2 & 5.9 \\
\hline College+ & 44.1 & 6.2 \\
\hline \multicolumn{3}{|l|}{ Race } \\
\hline White & 29.5 & 5.8 \\
\hline Hispanic & 29.2 & 5.6 \\
\hline Black & 26.3 & 7.0 \\
\hline Other & 23.0 & 5.1 \\
\hline All & 28.6 & 5.8 \\
\hline \multicolumn{3}{|l|}{ Age } \\
\hline 25 or under & 12.2 & 2.7 \\
\hline $26-54$ & 30.0 & 6.6 \\
\hline 55 or older & 29.0 & 5.7 \\
\hline \multicolumn{3}{|l|}{ Union Status } \\
\hline Union & 44.7 & 5.0 \\
\hline Non-union & 24.4 & 4.7 \\
\hline \multicolumn{3}{|l|}{ Private or Public } \\
\hline Private Company & 24.8 & 5.9 \\
\hline Public & 44.2 & 5.3 \\
\hline \multicolumn{3}{|l|}{ Type of Work } \\
\hline Provide Services & 31.2 & 5.9 \\
\hline Make Things & 11.4 & 5.1 \\
\hline Repair Things & 22.4 & 7.2 \\
\hline
\end{tabular}


Table 3

Requirements for Becoming Licensed

\begin{tabular}{lc}
\hline \hline Education Requirement & $\begin{array}{c}\text { \% of licensed workers } \\
\text { facing requirement }\end{array}$ \\
\hline College & 42.8 \\
High School & 31.2 \\
Exam & 85.0 \\
Continuing Ed & 69.8 \\
Internship & 51.1 \\
\hline
\end{tabular}

$\mathrm{N}=721$ from the PDII 
Table 4: Estimates of the Impact of Licensing on Wages

\begin{tabular}{|c|c|c|c|}
\hline & (1) & (2) & (3) \\
\hline & Log wage & Log wage & Log wage \\
\hline \multirow[t]{2}{*}{ Licensed } & $0.139 * \star \star$ & $0.183^{* * *}$ & $0.119 * * *$ \\
\hline & $(0.031)$ & $(0.033)$ & $(0.034)$ \\
\hline \multirow[t]{2}{*}{ Age } & $-0.008 * \star \star$ & $-0.005^{*}$ & $-0.0 \odot 8 * \star \star$ \\
\hline & $(0.003)$ & $(\odot .003)$ & $(\odot .0 \odot 3)$ \\
\hline \multirow[t]{2}{*}{ Education level } & $0.085^{* \star *}$ & $0.055^{* * *}$ & $0.063^{* * *}$ \\
\hline & $(0.005)$ & $(\odot .006)$ & $(\odot .006)$ \\
\hline \multirow[t]{2}{*}{ Union Member } & $0.088^{* \star}$ & $0.193^{* * *}$ & $0.143^{* * *}$ \\
\hline & $(0.038)$ & $(0.037)$ & $(\odot .04 \odot)$ \\
\hline \multirow[t]{2}{*}{ Government } & 0.005 & -0.007 & -0.032 \\
\hline & $(0.039)$ & $(0.038)$ & $(0.041)$ \\
\hline \multirow[t]{2}{*}{ Service } & 0.030 & -0.009 & -0.001 \\
\hline & $(0.035)$ & $(0.038)$ & $(0.039)$ \\
\hline \multirow[t]{2}{*}{ Self employed } & $0.183^{* * *}$ & $0.177^{* * *}$ & $0.229 * * *$ \\
\hline & $(0.049)$ & $(0.048)$ & $(0.053)$ \\
\hline \multirow[t]{2}{*}{ Gender } & $-0.262^{\star \star \star}$ & $-0.201^{* * *}$ & $-0.219^{* \star *}$ \\
\hline & $(0.028)$ & $(0.029)$ & $(0.031)$ \\
\hline \multirow[t]{2}{*}{ Work experience } & $0.049 * * *$ & $0.036^{* * *}$ & $0.043^{* * *}$ \\
\hline & $(0.005)$ & $(0.005)$ & $(0.005)$ \\
\hline \multirow[t]{2}{*}{ Work experience sq. } & $-0.001^{\star \star \star *}$ & $-0.001^{\star \star \star}$ & $-0.001^{\star \star *}$ \\
\hline & $(0.000)$ & $(0.000)$ & $(\odot .0 \odot \odot)$ \\
\hline \multirow[t]{2}{*}{ Hispanic } & $-0.130 * * *$ & $-0.117^{* * *}$ & $-0.107^{* \star *}$ \\
\hline & $(0.038)$ & $(0.036)$ & $(0.041)$ \\
\hline \multirow[t]{2}{*}{ Black } & $-0.167^{* * *}$ & $-0.165^{* * *}$ & $-0.159^{* * *}$ \\
\hline & $(0.042)$ & $(0.040)$ & $(0.045)$ \\
\hline \multirow[t]{2}{*}{ Asian } & $0.326 * * *$ & $0.192 * *$ & $0.258 * * *$ \\
\hline & $(\odot .086)$ & $(\odot .081)$ & $(\odot .097)$ \\
\hline \multirow[t]{2}{*}{ Constant } & $1.810^{* * *}$ & $2.149^{* * *}$ & 2.633 \\
\hline & $(\odot .093)$ & $(\odot .281)$ & $(1.827)$ \\
\hline Observations & 1732 & 1732 & 1732 \\
\hline $\mathrm{R}^{2}$ & 0.33 & 0.44 & 0.49 \\
\hline 2-digit occ. controls & No & Yes & No \\
\hline 4-digit occ. controls & No & No & Yes \\
\hline
\end{tabular}


Table 5: Analysis of Licensing and Certification on Wages

\begin{tabular}{|c|c|c|c|}
\hline & $(1)$ & $(2)$ & (3) \\
\hline & Log wage & Log wage & Log wage \\
\hline \multirow[t]{2}{*}{ Licensed } & $0.145^{\star \star \star}$ & $0.197 * \star \star$ & $0.127^{\star \star \star *}$ \\
\hline & $(0.031)$ & $(0.033)$ & $(0.035)$ \\
\hline \multirow[t]{2}{*}{ Certified } & 0.072 & $0.106^{*}$ & 0.075 \\
\hline & $(0.059)$ & $(0.056)$ & $(0.060)$ \\
\hline \multirow[t]{2}{*}{ Age } & $-0.008^{* * *}$ & $-0.005^{\star}$ & $-0.008 * * *$ \\
\hline & $(0.003)$ & $(0.003)$ & $(0.003)$ \\
\hline \multirow[t]{2}{*}{ Education Level } & $0.085^{* * *}$ & $0.054 * * *$ & $0.062 * * *$ \\
\hline & $(0.005)$ & $(0.006)$ & $(0.006)$ \\
\hline \multirow[t]{2}{*}{ Union Member } & $0.086^{\star \star}$ & $0.192^{* \star *}$ & $0.140^{* \star *}$ \\
\hline & $(0.038)$ & $(0.037)$ & $(0.040)$ \\
\hline \multirow[t]{2}{*}{ Government } & 0.006 & -0.005 & -0.031 \\
\hline & $(0.039)$ & $(0.038)$ & $(0.041)$ \\
\hline \multirow[t]{2}{*}{ Service } & 0.029 & -0.009 & -0.001 \\
\hline & $(0.035)$ & $(0.038)$ & $(0.039)$ \\
\hline \multirow[t]{2}{*}{ Self employment } & $0.179 * \star *$ & $0.171^{* * *}$ & $0.225^{\star \star *}$ \\
\hline & $(0.049)$ & $(0.048)$ & $(0.053)$ \\
\hline \multirow[t]{2}{*}{ Gender } & $-0.260 * \star \star$ & $-0.197^{\star * \star} \star$ & $-0.218 * \star \star$ \\
\hline & $(0.028)$ & $(0.029)$ & $(0.031)$ \\
\hline \multirow[t]{2}{*}{ Work Experience } & $0.049 * \star *$ & $0.036^{* \star *}$ & $0.043^{* \star *}$ \\
\hline & $(0.005)$ & $(0.005)$ & $(0.005)$ \\
\hline \multirow[t]{2}{*}{ Work Experience sq. } & $-0.001^{* * *}$ & $-0.001^{* \star *}$ & $-0.001^{* \star *}$ \\
\hline & $(0.000)$ & $(0.000)$ & $(0.000)$ \\
\hline \multirow[t]{2}{*}{ Hispanic } & $-0.133^{* * *}$ & $-0.122^{* \star \star}$ & $-0.109 * \star \star$ \\
\hline & $(0.038)$ & $(0.036)$ & $(0.041)$ \\
\hline \multirow[t]{2}{*}{ Black } & $-0.168 * \star \star$ & $-0.166 * \star \star$ & $-0.160 * \star \star *$ \\
\hline & $(0.042)$ & $(0.040)$ & $(0.045)$ \\
\hline \multirow[t]{2}{*}{ Asian } & $0.326^{\star \star \star}$ & $0.195 * *$ & $0.257^{\star \star \star}$ \\
\hline & $(\odot . \odot 86)$ & $(\odot .081)$ & $(\odot .097)$ \\
\hline \multirow[t]{2}{*}{ Constant } & $1.816^{* * *}$ & $2.165^{\star * *}$ & 2.644 \\
\hline & $(0.093)$ & $(0.281)$ & $(1.826)$ \\
\hline Observations & 1732 & 1732 & 1732 \\
\hline $\mathrm{R}^{2}$ & 0.33 & 0.44 & 0.49 \\
\hline 2-digit occ. controls & No & Yes & No \\
\hline 4-digit occ. controls & No & No & Yes \\
\hline
\end{tabular}


Table 6: Governmental Level of the License and Wage Determination

\begin{tabular}{|c|c|c|c|}
\hline & (1) & (2) & (3) \\
\hline & Log wage & Log wage & Log wage \\
\hline \multirow[t]{2}{*}{ State only } & $0.154^{* * *}$ & $0.173^{* * *}$ & $0.087^{*}$ \\
\hline & $(0.046)$ & $(0.047)$ & $(0.049)$ \\
\hline \multirow[t]{2}{*}{ Federal only } & $0.256^{* \star \star}$ & $0.200^{* * *}$ & 0.128 \\
\hline & $(0.078)$ & $(0.075)$ & $(0.083)$ \\
\hline \multirow{2}{*}{ Local only } & 0.089 & 0.130 & 0.196 \\
\hline & $(0.121)$ & $(0.120)$ & $(0.137)$ \\
\hline \multirow[t]{2}{*}{ Licensed, Not used } & 0.116 & 0.164 & 0.062 \\
\hline & $(0.128)$ & $(0.120)$ & $(0.144)$ \\
\hline \multirow[t]{2}{*}{ State and Federal } & $0.209 * * *$ & $0.257^{* * *}$ & $0.227^{* \star *}$ \\
\hline & $(0.060)$ & $(0.059)$ & $(0.062)$ \\
\hline \multirow[t]{2}{*}{ State and Local } & $0.195^{* \star *}$ & $0.261^{* \star \star}$ & $0.213^{* * *}$ \\
\hline & $(0.075)$ & $(0.072)$ & $(0.079)$ \\
\hline \multirow[t]{2}{*}{ Federal and local } & -0.080 & -0.085 & -0.059 \\
\hline & $(0.226)$ & $(0.210)$ & $(0.218)$ \\
\hline \multirow[t]{2}{*}{ State, federal, loc. } & -0.021 & 0.068 & -0.023 \\
\hline & $(0.052)$ & $(0.052)$ & $(0.056)$ \\
\hline \multirow[t]{2}{*}{ Age } & $-0.008^{* *}$ & $-0.005^{*}$ & $-0.008^{* * *}$ \\
\hline & $(0.003)$ & $(0.003)$ & $(0.003)$ \\
\hline \multirow[t]{2}{*}{ Education level } & $0.085^{* * *}$ & $0.054^{* * *}$ & $0.063^{* * *}$ \\
\hline & $(0.006)$ & $(0.006)$ & $(0.006)$ \\
\hline \multirow[t]{2}{*}{ Union Member } & $0.084^{* \star}$ & $0.185^{* \star \star}$ & $0.131^{* \star *}$ \\
\hline & $(0.039)$ & $(0.037)$ & $(0.041)$ \\
\hline \multirow[t]{2}{*}{ Government } & 0.019 & 0.012 & -0.014 \\
\hline & $(0.039)$ & $(0.038)$ & $(0.041)$ \\
\hline \multirow[t]{2}{*}{ Service } & 0.026 & -0.014 & 0.010 \\
\hline & $(0.035)$ & $(0.038)$ & $(0.039)$ \\
\hline \multirow[t]{2}{*}{ Self Employment } & $0.171^{\star \star \star}$ & $0.165^{* * *}$ & $0.227^{\star \star \star}$ \\
\hline & $(0.050)$ & $(0.049)$ & $(0.053)$ \\
\hline \multirow[t]{2}{*}{ Gender } & $-0.261^{\star \star \star}$ & $-0.195^{\star * *}$ & $-0.214^{\star * *}$ \\
\hline & $(0.028)$ & $(0.029)$ & $(0.031)$ \\
\hline \multirow[t]{2}{*}{ Work experience } & $0.047^{* * *}$ & $0.036^{* * *}$ & $0.043^{* * *}$ \\
\hline & $(0.005)$ & $(0.005)$ & $(0.005)$ \\
\hline \multirow[t]{2}{*}{ Work experience sq. } & $-0.001^{* * *}$ & $-0.000^{* * *}$ & $-0.001^{* * *}$ \\
\hline & $(0.000)$ & $(0.000)$ & $(0.000)$ \\
\hline \multirow[t]{2}{*}{ Hispanic } & $-0.128^{* \star *}$ & $-0.115^{* \star *}$ & $-0.093^{* *}$ \\
\hline & $(0.038)$ & $(0.036)$ & $(0.041)$ \\
\hline \multirow[t]{2}{*}{ Black } & $-0.170^{* \star \star}$ & $-0.166^{\star \star \star}$ & $-0.154^{\star * \star}$ \\
\hline & $(0.043)$ & $(0.041)$ & $(0.045)$ \\
\hline \multirow[t]{2}{*}{ Asian } & $0.261^{* * *}$ & 0.117 & $0.186^{*}$ \\
\hline & $(0.089)$ & $(0.084)$ & $(0.101)$ \\
\hline \multirow[t]{2}{*}{ Constant } & $1.807^{* \star *}$ & $2.158^{\star \star \star}$ & 1.741 \\
\hline & $(0.094)$ & $(0.280)$ & $(1.209)$ \\
\hline Observations & 1708 & 1708 & 1708 \\
\hline $\mathrm{R}^{2}$ & 0.34 & 0.44 & 0.49 \\
\hline 2-digit occ. controls & No & Yes & No \\
\hline 4-digit occ. controls & No & No & Yes \\
\hline
\end{tabular}

Standard errors in parentheses.

* significant at $10 \%$; ** significant at $5 \% ; * * *$ significant at $1 \%$ 
Table 7: How Licensing Requirements Influence Wage Determination

\begin{tabular}{|c|c|c|c|}
\hline & Log wage & Log wage & Log wage \\
\hline \multirow[t]{2}{*}{ College } & $0.171^{\star \star}$ & 0.072 & 0.053 \\
\hline & $(0.067)$ & $(\odot .072)$ & $(0.074)$ \\
\hline \multirow{2}{*}{ H.S. diploma } & 0.086 & 0.073 & 0.027 \\
\hline & $(\odot .057)$ & $(0.054)$ & $(0.061)$ \\
\hline \multirow[t]{2}{*}{ Internship } & $-0.120^{* *}$ & -0.019 & -0.032 \\
\hline & $(0.057)$ & $(0.056)$ & $(0.061)$ \\
\hline \multirow[t]{2}{*}{ Test } & 0.057 & 0.039 & 0.023 \\
\hline & $(0.058)$ & $(0.054)$ & $(0.058)$ \\
\hline \multirow[t]{2}{*}{ Specific Tasks } & -0.040 & 0.064 & -0.012 \\
\hline & $(0.051)$ & $(0.048)$ & $(0.054)$ \\
\hline \multirow[t]{2}{*}{ Fees } & 0.046 & 0.056 & 0.080 \\
\hline & $(0.049)$ & $(0.047)$ & $(0.051)$ \\
\hline \multirow[t]{2}{*}{ Continuing ed. } & 0.007 & -0.017 & 0.008 \\
\hline & $(0.055)$ & $(0.051)$ & $(0.056)$ \\
\hline \multirow[t]{2}{*}{ Periodic Tests } & 0.040 & 0.050 & -0.002 \\
\hline & $(0.055)$ & $(0.052)$ & $(0.057)$ \\
\hline \multirow[t]{2}{*}{ Year or longer Intern } & 0.056 & 0.048 & $0.139^{\star}$ \\
\hline & $(0.068)$ & $(0.065)$ & $(0.071)$ \\
\hline \multirow[t]{2}{*}{ Age } & $-0.008^{\star \star *}$ & $-0.005^{*}$ & $-0.008^{* * *}$ \\
\hline & $(0.003)$ & $(0.003)$ & $(0.003)$ \\
\hline \multirow[t]{2}{*}{ Education } & $0.079 * \star \star$ & $0.053^{* * *}$ & $0.060^{* * *}$ \\
\hline & $(0.006)$ & $(0.006)$ & $(0.006)$ \\
\hline \multirow[t]{2}{*}{ Union member } & $0.105^{* \star *}$ & $0.203^{* \star *}$ & $0.148 * \star *$ \\
\hline & $(\odot .039)$ & $(\odot .037)$ & $(0.041)$ \\
\hline \multirow[t]{2}{*}{ Government } & 0.008 & -0.005 & -0.025 \\
\hline & $(0.039)$ & $(0.038)$ & $(0.041)$ \\
\hline \multirow[t]{2}{*}{ Service } & 0.026 & -0.007 & 0.002 \\
\hline & $(0.035)$ & $(0.038)$ & $(0.039)$ \\
\hline \multirow[t]{2}{*}{ Self Employment } & $0.189^{* \star *}$ & $0.180^{* \star *}$ & $0.218^{\star \star *}$ \\
\hline & $(0.050)$ & $(0.048)$ & $(0.054)$ \\
\hline \multirow[t]{2}{*}{ Gender } & $-0.265^{\star \star \star}$ & $-0.195^{\star * \star}$ & $-0.216^{* * *}$ \\
\hline & $(0.028)$ & $(0.029)$ & $(0.031)$ \\
\hline \multirow[t]{2}{*}{ Work experience } & $0.048^{* * *}$ & $0.036^{* * *}$ & $0.043^{* * *}$ \\
\hline & $(0.005)$ & $(0.005)$ & $(0.005)$ \\
\hline \multirow[t]{2}{*}{ Work experience $^{2}$} & $-0.001^{* * *}$ & $-0.001^{\star \star \star}$ & $-0.001^{\star \star \star}$ \\
\hline & $(0.000)$ & $(0.000)$ & $(0.000)$ \\
\hline \multirow[t]{2}{*}{ Hispanic } & $-0.126^{* \star *}$ & $-0.112^{* \star *}$ & $-0.106^{* * *}$ \\
\hline & $(0.038)$ & $(0.036)$ & $(0.041)$ \\
\hline \multirow[t]{2}{*}{ Black } & $-0.152^{* * *}$ & $-0.156^{* * *}$ & $-0.147^{* * *}$ \\
\hline & $(0.042)$ & $(0.040)$ & $(0.045)$ \\
\hline \multirow[t]{2}{*}{ Asian } & $0.303^{* * *}$ & $0.188^{* *}$ & $0.236^{* *}$ \\
\hline & $(0.085)$ & $(\odot .081)$ & $(0.096)$ \\
\hline \multirow[t]{2}{*}{ Constant } & $1.880^{* * *}$ & $2.699 * * *$ & 2.672 \\
\hline & $(\odot .096)$ & $(0.158)$ & $(1.826)$ \\
\hline F-test for Reg. & 3.97 & 3.97 & 2.22 \\
\hline Observation & 1741 & 1741 & 1741 \\
\hline $\mathrm{R}^{2}$ & 0.33 & 0.43 & 0.49 \\
\hline 2-digit occ. controls & No & Yes & No \\
\hline 4-digit occ. controls & No & No & Yes \\
\hline
\end{tabular}


Table 8: Influence of Licensing and Certification and Reading Usage

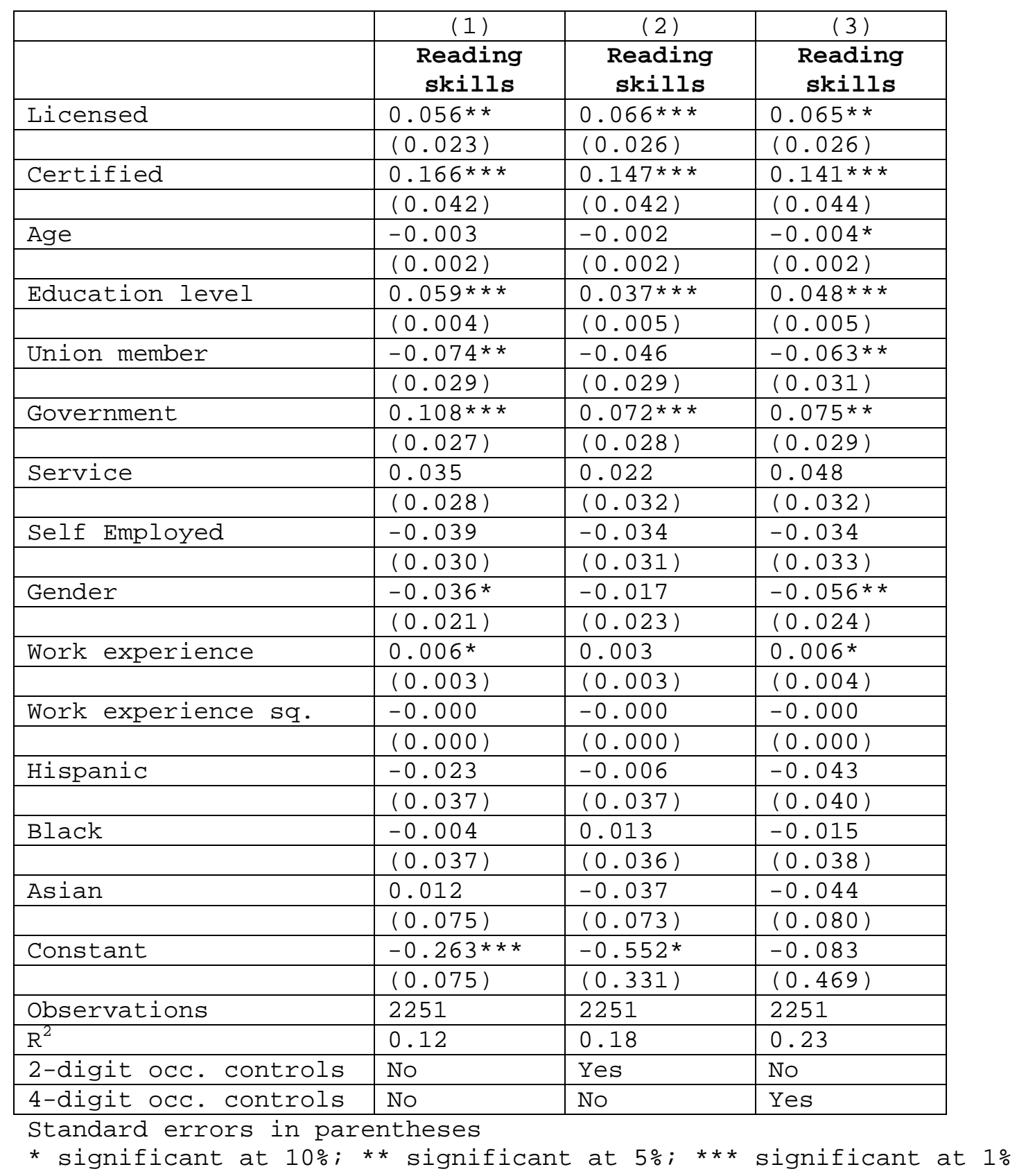


Table 9: Influence of Licensing and Certification and Math Skills and Usage

\begin{tabular}{|c|c|c|c|}
\hline & $(1)$ & $(2)$ & $(3)$ \\
\hline & $\begin{array}{c}\text { Math } \\
\text { skills }\end{array}$ & $\begin{array}{c}\text { Math } \\
\text { skills }\end{array}$ & $\begin{array}{c}\text { Math } \\
\text { skills }\end{array}$ \\
\hline \multirow[t]{2}{*}{ Licensed } & $0.063^{* * *}$ & $\odot .083^{* * *}$ & 0.030 \\
\hline & $(0.023)$ & $(\odot .026)$ & $(0.026)$ \\
\hline \multirow[t]{2}{*}{ Certified } & $0.092^{* \star}$ & $0.083^{* *}$ & 0.056 \\
\hline & $(0.042)$ & $(0.042)$ & $(0.044)$ \\
\hline \multirow[t]{2}{*}{ Age } & $-0.007^{\star \star *}$ & $-0.006^{* * *}$ & $-0.006^{* * *}$ \\
\hline & $(0.002)$ & $(0.002)$ & $(0.002)$ \\
\hline \multirow[t]{2}{*}{ Education level } & $0.041^{* * *}$ & $0.029 * * *$ & $0.033^{* * *}$ \\
\hline & $(0.004)$ & $(0.005)$ & $(0.005)$ \\
\hline \multirow[t]{2}{*}{ Union member } & $-0.060^{* *}$ & $-0.059^{*} *$ & -0.044 \\
\hline & $(0.030)$ & $(\odot .029)$ & $(0.031)$ \\
\hline \multirow[t]{2}{*}{ Government } & -0.001 & $-0.0 \odot 4$ & $\odot .027$ \\
\hline & $(0.027)$ & $(0.028)$ & $(0.029)$ \\
\hline \multirow[t]{2}{*}{ Service } & $-0.171^{\star * *}$ & $-0.103^{* * *}$ & $-0.168^{* * *}$ \\
\hline & $(0.029)$ & $(0.032)$ & $(0.032)$ \\
\hline \multirow[t]{2}{*}{ Self employed } & -0.024 & -0.032 & -0.020 \\
\hline & $(0.030)$ & $(0.031)$ & $(0.033)$ \\
\hline \multirow[t]{2}{*}{ Gender } & $-0.133^{\star * *}$ & $-0.092^{* * *}$ & $-0.122^{* * *}$ \\
\hline & $(0.021)$ & $(0.023)$ & $(0.023)$ \\
\hline \multirow[t]{2}{*}{ Work experience } & 0.006 & 0.002 & 0.005 \\
\hline & $(0.004)$ & $(0.003)$ & $(0.004)$ \\
\hline \multirow[t]{2}{*}{ Work experience sq. } & -0.000 & 0.000 & -0.000 \\
\hline & $(0.00 \odot)$ & $(0.00 \odot)$ & $(0.000)$ \\
\hline \multirow[t]{2}{*}{ Hispanic } & $0.125^{* \star *}$ & $0.131^{* * *}$ & $0.121^{* * *}$ \\
\hline & $(0.038)$ & $(\odot . \odot 37)$ & $(0.039)$ \\
\hline \multirow[t]{2}{*}{ Black } & -0.026 & 0.013 & -0.003 \\
\hline & $(0.037)$ & $(0.036)$ & $(0.038)$ \\
\hline \multirow[t]{2}{*}{ Asian } & 0.010 & -0.036 & -0.015 \\
\hline & $(\odot . \odot 76)$ & $(0.074)$ & $(0.080)$ \\
\hline \multirow[t]{2}{*}{ Constant } & $0.351^{* * *}$ & 0.435 & 0.246 \\
\hline & $(\odot .076)$ & $(0.334)$ & $(0.469)$ \\
\hline Observations & 2251 & 2251 & 2251 \\
\hline $\mathrm{R}^{2}$ & 0.10 & 0.16 & 0.22 \\
\hline 2-digit occ. controls & No & Yes & No \\
\hline 4-digit occ. controls & No & No & Yes \\
\hline
\end{tabular}


Table 10: Impact of Licensing and Unions on Wage Dispersion

\begin{tabular}{|c|c|c|c|c|}
\hline \multicolumn{5}{|l|}{$\begin{array}{c}\text { Union wage } \\
\text { variation }\end{array}$} \\
\hline \multirow[t]{2}{*}{ Occupation Category } & \multicolumn{2}{|c|}{ mean within category squared residual } & \multirow{2}{*}{$\begin{array}{l}\text { coefficient: (difference in } \\
\text { mean squared error union - } \\
\text { nonunion) }\end{array}$} & \multirow[t]{2}{*}{$p$-value } \\
\hline & union & nonunion & & \\
\hline Service & 0.186 & 0.315 & -0.13 & 0.007 \\
\hline Repair & 0.285 & 0.269 & 0.02 & 0.877 \\
\hline Manufacturing & 0.163 & 0.317 & -0.15 & 0.227 \\
\hline All & 0.192 & 0.312 & -0.12 & 0.004 \\
\hline \multicolumn{4}{|l|}{$\begin{array}{l}\text { Licensing wage } \\
\text { variation }\end{array}$} & \\
\hline \multirow[t]{2}{*}{ Occupation Category } & \multicolumn{2}{|c|}{ mean within category squared residual } & $\begin{array}{l}\text { coefficient: (difference in } \\
\text { mean squared error license - } \\
\text { unlicensed) }\end{array}$ & $p$-value \\
\hline & licensed & unlicensed & & \\
\hline Service & 0.262 & 0.304 & -0.04 & 0.287 \\
\hline Repair & 0.247 & 0.280 & -0.03 & 0.753 \\
\hline Manufacturing & 0.403 & 0.274 & 0.13 & 0.364 \\
\hline All & 0.267 & 0.299 & -0.03 & 0.384 \\
\hline
\end{tabular}


Appendix

Comparing Log Wage Regressions: CPS and PDII

Explanatory Variable

CPS PDII

Intercept

$\begin{array}{ll}1.016 & 1.260 \\ (0.019) & (0.073)\end{array}$

Education

$\begin{array}{lc}0.110 & 0.103 \\ (0.001) & (0.005)\end{array}$

Pot. Experience

$\begin{array}{ll}0.036 & 0.036 \\ (0.001) & (0.003)\end{array}$

Experience-Squared

(/100)

$\begin{array}{ll}-0.058 & -0.056\end{array}$

Female

(0.002)

(0.006)

$-0.214 \quad-0.308$

$\mathrm{R}^{2}$

(0.007)

(0.027)

0.367

0.326

Sample Size

18,944

1,675

Notes: Sample weights used in both regressions. CPS data are for the months June and July of 2007. 